\title{
Penggunaan Non-Steroid Antiinflamatory Drug dan Potensi Interaksi Obatnya Pada Pasien Muskuloskeletal
}

\section{Isnenia ${ }^{1 *}$}

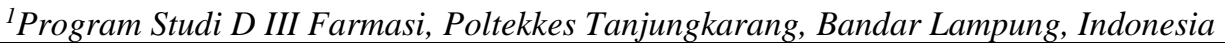

\section{INFO ARTIKEL}

Sejarah artikel:

Penerimaan

naskah: 23

November 2020

Penerimaan

naskah revisi: 10

Desember 2020

Disetujui untuk

dipublikasikan: 10

Desember 2020

\section{Kata kunci :}

NSAID, Interaksi

Obat

Muskuloskeletal

\section{A B S T R A K}

Terapi utama dalam mengatasi nyeri pada pasien muskuloskeletal adalah penggunaan non steroid antiinflamatory drugs (NSAIDs) baik sebagai monoterapi atau kombinasi dengan obat dari golongan yang sama atau penghilang nyeri dari golongan lainnya. Selain terapi obat yang bersifat simtomatis, diberikan juga obat yang bersifat kausatif. Pemakaian lebih dari satu obat berpotensi menimbulkan interaksi yang dapat mempengaruhi outcome. Penelitian ini bertujuan untuk melihat karakteristik sosiodemografi (jenis kelamin, usia), klinis (jumlah obat, jenis obat yang digunakan, jenis diagnosa) pasien, serta mencari hubungan potensi interaksi obat dengan variabel tersebut. Penelitian ini merupakan penelitian kuantitatif dengan desain cross sectional. Data diambil dari 100 rekam medik pasien _yang terdiagnosa lima besar penyakit muskuloskeletal_pada sebuah rumah sakit tipe C di Bandar Lampung. Data dianalisis secara deskriptif untuk jenis kelamin, usia, jumlah obat, jenis obat, dan potensi interaksi obat. Analisis korelasi bivariate Chi-Square antara variabel potensi interaksi obat dengan jenis kelamin, usia, jenis diagnosa, jenis NSAID. Hasil penelitian menunjukkan bahwa pasien muskuloskeletal berjenis kelamin laki-laki sebesar 44\%, perempuan 56\%. Pasien muskuloskeletal terbanyak pada usia 18-65 tahun (78\%). Pasien yang memperoleh obat $<5$ sejumlah $68 \%$ dan $\geq 5$ sebesar $32 \%$. 54\% pasien menggunakan NSAID diklofenak, hanya 5\% pasien menggunakan kombinasi dua obat NSAID (diklofenak-ibuprofen). 22\% pasien berpotensi mengalami interaksi obat. Tidak ada hubungan bermakna $(p>0,05)$ antara potensi interaksi obat dengan usia, jenis kelamin, jenis NSAID, dan jenis diagnosa.

\section{The Use of Non-Steroid Antiinflamatory Drugs and It's Drug-Drug Interaction on Musculosceletal Patients}

Keywords:

NSAIDs, Drug

Interaction,

Musculoskeletal

\section{A B S T R A C T}

The main therapy on musculoskeletal patients is the use of non-steroidal anti-inflammatory drugs (NSAIDs) either as monotherapy or in combination with drugs of the same class or pain relievers from other groups. The use of more than one drugs have potentially caused drug-drug interactions that can affect to patient. This study was aimed to describe the patient's sociodemographic (sex, ages) and clinical (numbers of drugs, type of drugs and diagnose) characteristics, as well as to find the correlation between potential drug interactions with these variables. This research was a quantitative study with a cross sectional design. Data were taken from 100 medical records of patients who had diagnosed with top five musculoskeletal diseases. Data were analyzed descriptively for sex, ages, number of drugs, type of drugs, and potential drug interactions. Bivariate correlation with chi-square were conducted to find statistically significancy potential drug interactions with each variable consist of sex, ages, type of drugs and it's diagnose. The result shows that the musculoskeletal patients were $44 \%$ male, $56 \%$ female. Most musculoskeletal patients were aged $18-65$ years $(78 \%)$. Patients who received drugs $<5$ were $68 \%$ and $\geq$ 5 were $32 \% .54 \%$ of patients were taking the diclofenac and only $5 \%$ of patients were taking the two NSAIDs combination, diclofenac and ibuprofen. There was no significant correlation $(p>0,05)$ between potential drug interactions with age, sex, type of NSAID, and type of musculosceletal diseases. 


\section{Pendahuluan}

Penyakit pada sistem muskuloskeletal meliputi bagian tulang, sendi, otot, tulang belakang, dan jaringan lain seperti tendon dan ligamen. Penyakit pada sistem muskuloskeletal mulai dari yang bersifat akut, seperti patah tulang, keseleo dan ketegangan otot serta yang bersifat kronis yaitu nyeri dan kecacatan yang berlangsung lama. Penyakit muskuloskeletal yang paling umum dengan tingkat disabilitas yang tinggi adalah osteoarthritis, nyeri punggung dan leher, patah tulang yang berhubungan dengan kerapuhan tulang, cedera dan kondisi peradangan sistemik seperti rheumatoid arthritis ${ }^{1}$ Penyakit muskuloskeletal yang bersifat degeneratif dan terdapat inflamasi berkaitan dengan rasa nyeri. Hal ini yang menyebabkan banyak orang mencari fasilitas pelayanan kesehatan sebagai pasien rawat jalan $(20 \%)$ dan $12 \%$ mendapatkan resep ${ }^{2}$.

Lini pertama dalam mengatasi rasa nyeri adalah asetaminofen dan NSAID ${ }^{2}$. Penggunaan topikal NSAID sama efektifnya dengan NSAID oral, tetapi hanya digunakan untuk nyeri pada struktur tubuh superficial saja. Tramadol atau obat-obatan opioid dapat digunakan jika obat lini pertama dikontraindikasikan, tidak dapat ditoleransi, atau tidak efektif untuk nyeri akut ${ }^{3}$. Obat lain yang dapat diberikan meliputi relaksan otot rangka, bifosfonat (alendronat, risedronat, ibandronat, asam zoledronat), hormon peptida (teriparatid dan calcitonin), estrogen dan raloxifene untuk wanita postmenopause, suplemen kalsium, vitamin D, antidepresan, benzodiazepin, analgesik opioid, asam hialuronat, nutraseutikal (glukosamin, kondroitin) $)^{3,4}$.

Interaksi obat-obat merupakan penyebab paling umum dari medication error di negara-negara berkembang. Interaksi ini dapat dikarenakan perubahan dalam absorpsi, distribusi, metabolisme,ekskresi, dan farmakodinamik ${ }^{5,6}$. Sebuah studi yang dilakukan di Kroasia, dilaporkan sebanyak $27,07 \%$ terjadi reaksi yang tidak diinginkan dikarenakan interaksi obat. Reaksi ini menjadi salah satu penyebab kematian dan morbiditas yang akhirnya berdampak luas pada timbulnya komplikasi dan lama rawat inap meningkat, serta menjadi penyebab masuk rumah sakit $^{6,7}$.

Interaksi antara NSAID (anti-inflamasi nonsteroid) dengan obat lain terjadi lebih sering dikarenakan NSAID adalah salah satu obat yang paling banyak digunakan. Interaksi ini ada yang berdampak tidak signifikan pada outcome klinik, tetapi ada juga yang memberikan dampak serius/membahayakan nyawa, khususnya pada obat-obat dengan jendela terapi sempit pada penyakit dengan tingkat keseriusan tinggi, seperti oral antikoagulan, glikosida, antiaritmia, antikonvulsan, dan sitotoksik $^{7}$. Potensi interaksi dapat muncul pada usia berapa pun, tetapi frekuensi terjadinya pada kondisi polifarmasi dan usia yang lebih tua dengan prevalensi $20-40 \%{ }^{6,7}$.

Penelitian ini bertujuan untuk melihat hubungan antara potensi interaksi obat NSAID dengan variable usia, jenis kelamin, jenis NSAID, dan jenis diagnosa muskuloskeletal.

\section{Metode}

Penelitian ini merupakan penelitian kuantitatifanalitik yang bersifat cross-sectional. Data yang diambil bersifat retrospektif pada tahun 2017. Sampel yang digunakan penelitian ini adalah rekam medik pasien rawat jalan yang didiagnosa lima besar penyakit muskuloskeletal pada sebuah rumah sakit di Kota Bandar Lampung. Sampel dihitung dengan menggunakan rumus Slovin dengan taraf siginifikansi sebesar 10\%. Populasi pada tahun 2017 diketahui sebanyak 3000 pasien sehingga diperoleh sampel sebesar 100 pasien. Setiap diagnosa diambil 20 pasien. Sampel diambil secara kuota sampling.

\section{Pengumpulan Data}

Pengumpulan data dilakukan dengan memilih rekam medik pasien dan mencatat data yang diperlukan pada lembar pengumpul data. Data tersebut yaitu umur, jenis kelamin, jumlah obat, jenis obat yang digunakan, jenis diagnosa.

\section{Analisis Data}

Data yang diperoleh kemudian dianalisis secara deskriptif untuk menggambarkan masing-masing variabel umur, jenis kelamin, jumlah obat, jenis NSAID, jenis obat non NSAID yang digunakan, dan potensi interaksi obat. Potensi interaksi obat diperoleh dengan bantuan mesin pencarian drug interaction checker Medscape.

Analisis secara bivariat dilakukan terhadap potensi interaksi obat dengan masing-masing variable. Analisis bivariat dengan menggunakan Chi-Square. Jika $p<0,05$ maka terdapat hubungan bermakna antara variabel dengan potensi interaksi obat.

\section{Hasil dan Diskusi}

Karakteristik sampel dalam penelitian ini seperti terlihat dalam tabel 1. Prevalensi nyeri muskuloskeletal secara signifikan lebih sering terjadi pada wanita dibandingkan laki-laki. Peningkatan umur meningkatkan prevalensi pada kedua kelompok tersebut ${ }^{9,10}$.

Prevalensi penyakit muskuloskeletal lebih banyak pada orang tua. Penyakit ini merupakan penyebab nyeri hebat dalam jangka waktu yang lama dan menyerang ratusan ribu orang dari jutaan orang di muka bumi ${ }^{10}$. Studi yang dilakukan di Finlandia, 35\% penduduk menderita nyeri kornis dan 40\%-nya mencari pengobatan ke pelayanan kesehatan pertama akibat nyeri. Rasa nyeri ini dapat berlangsung hingga 4 tahun. Pada negara berkembang, 1 dari 4 orang menderita nyeri muskuloskeletal ${ }^{11}$.

Tabel 1. Karakteristik Sosiodemografi dan Klinis

Karakteristik \%




\begin{tabular}{rll}
\hline \multicolumn{2}{l}{ Jenis Kelamin } & \\
1. & Laki-laki & 44 \\
2. & Perempuan & 56 \\
& & \\
\hline Usia & & \\
1. & $0-17$ & 2 \\
2. & $18-65$ & 78 \\
3. & $66-79$ & 18 \\
4. & $>80$ & 2
\end{tabular}

\begin{tabular}{lll}
\hline Jenis NSAID & \\
1. & Asam mefenamat & 1 \\
2. & Diklofenak & 49 \\
3. & Ibuprofen & 2 \\
4. & Ketoprofen & 2 \\
5. & Piroksikam & 3 \\
6. & Meloksikam & 25 \\
7. & Etoricoxib & 13 \\
8. & Diklofenak-Ibuprofen & 5
\end{tabular}

\begin{tabular}{cc}
\hline Jumlah Obat & \\
$1 . \quad<5$ obat & 68 \\
2. $\quad \geq 5$ obat & 32 \\
Potensi Interaksi Obat & \\
1. Tidak ada & 78 \\
2. Ada & 22 \\
\hline
\end{tabular}

Studi yang dilakukan di Ghana terhadap orang tua, wanita baik di daerah perkotaan dan pedesaan memiliki prevalensi penyakit muskuloskeletal lebih tinggi dibandingkan pria. Pada populasi ini, semakin meningkat usia maka kejadian penyakit ini akan semakin meningkat ${ }^{11}$. Hal yang sama juga terjadi populasi yang bersifat umum ${ }^{12}$. Secara anatomi, komponen penyusun otot, hormon, dan genetik terdapat perbedaan antara laki-laki dan perempuan. Perempuan memiliki prevalensi yang lebih tinggi pada berbagai penyakit muskuloskeletal, misalnya osteoporosis, osteoartritis, pergelangan kaki, ligamen, dan tendon ${ }^{13}$.

NSAID baik selektif atau non selektif memiliki aktivitas analgesia, antiinflamasi, yang diperlukan untuk mengatasi nyeri kronis dan memiliki keefektifan yang mirip ${ }^{14}$. Penggunaan tunggal atau kombinasi dengan obat lain dari kelas yang berbeda terbukti efektif mengurangi nyeri akut dan kronis pada pasien muskuloskeletal ${ }^{15}$. Jika dibandingkan dengan parasetamol, NSAID lebih baik dalam menghilangkan nyeri pada penderita osteoarthritis, tetapi profil keamanannya lebih baik parasetamol ${ }^{16,17}$.

Jenis NSAID yang digunakan dalam penelitian paling banyak adalah diklofenak (49\%), meloksikam (25\%), dan etoricoxib (13\%). Hal yang sama juga dinyatakan bahwa diklofenak merupakan NSAID yang paling popular, diikuti ibuprofen, asam mefenamat, dan naproksen berdasarkan data penjualan dan daftar obat esensial di beberapa Negara ${ }^{15}$.

Penggunaan NSAID menjadi terbatas dikarenakan efek samping pada saluran pencernaan dan sistem kardiovaskuler ${ }^{18}$. Diklofenak dibandingkan jenis NSAID yang lain merupakan yang paling efektif dalam mengatasi nyeri dan telah ditetapkan sebagai drug of choice dalam mengatasi osteoarthritis ${ }^{16}$.

NSAID selektif, yaitu COX-2 (cyclooxygenase-2) selective inhibitor digunakan sebesar $13 \%$ dalam penelitian ini. Etoricoxib menempati urutan keempat terhadap keseluruhan penggunaan NSAID ${ }^{15}$. Data klinis menunjukkan bahwa COX-2 Inhibitor mempunyai efikasi yang sama atau lebih baik dibandingkan tradisional NSAID (non selektif) ${ }^{14,17}$. Untuk mengatasi nyeri kronik, pemilihan NSAID dengan $t \frac{1}{2}$ yang panjang (naproksen dan COX-2 inhibitor) menunjukkan keuntungan akibat aturan pakai yang 1-2 kali sehari ${ }^{17}$.

Sebesar 5\% sampel yang menggunakan NSAID kombinasi, yaitu diklofenak dan ibuprofen. Kombinasi keduanya, selain meningkatkan efek penghilang nyeri, juga meningkatkan efek samping akibat penggunaan NSAID.

Enam puluh delapan persen sampel mendapatkan kurang dari 5 obat dan $32 \%$ mendapatkan $\geq 5$ obat. Rerata obat yang diresepkan sebesar 4,33. Jenis obat selain NSAID yang diresepkan terlihat pada tabel 2 .

Seperti yang terlihat pada tabel 2 , antitukak adalah obat yang paling banyak diresepkan bersamaan dengan NSAID. Jenis antitukak yang diresepkan meliputi proton pump inhibitor (PPI) (74,03\%), H2-blocker (16,88\%), sukralfat (2,6\%), dan antasida (6,49\%). Menurut The American Arthritis, Rheumatism and Aging Medical System (ARAMIS), 19,9\% NSAID diresepkan dengan antasida, $11 \%$ dengan $\mathrm{H} 2$ bloker, dan $0,9 \%$ dengan sukralfat $^{19}$.

Tabel 2. Jenis Obat yang Diresepkan Selain NSAID

\begin{tabular}{lcc}
\hline \multicolumn{1}{c}{ Jenis Obat (Selain NSAID) } & $\begin{array}{c}\text { Jumlah } \\
\text { (pasien) }\end{array}$ & $\begin{array}{c}\text { Persentase } \\
(\%)\end{array}$ \\
\hline Antitukak & 77 & $77,00 \%$ \\
\hline Analgetika Narkotika & 56 & $56,00 \%$ \\
\hline Analgetika Non Narkotik & 35 & $35,00 \%$ \\
\hline Relaksan Otot & 34 & $34,00 \%$ \\
\hline Antiepilepsi & 29 & $29,00 \%$ \\
\hline Antidepresan & 27 & $27,00 \%$ \\
\hline Kortikosteroid & 19 & $19,00 \%$ \\
\hline Antihipertensi & 11 & $11,00 \%$ \\
\hline Vitamin Neurotropik & 11 & $11,00 \%$ \\
\hline Antiemetik & 5 & $5,00 \%$ \\
\hline Antibiotik & 4 & $4,00 \%$ \\
\hline Ekspektoran & 2 & $2,00 \%$ \\
\hline Antiansietas & 2 & $2,00 \%$ \\
\hline Antipirai & 2 & $2,00 \%$ \\
\hline Antimigrain & 2 & $2,00 \%$ \\
\hline Suplemen Tulang & 1 & $1,00 \%$ \\
\hline Antiasma & 1 & $1,00 \%$ \\
\hline Antiflu-Batuk & 1 & $1,00 \%$ \\
\hline Antiaritmia & 1 & $1,00 \%$ \\
\hline Diuretik & 1 & $1,00 \%$ \\
\hline Antikanker Prostat & 1 & $1,00 \%$ \\
\hline Antihistamin & 1 & $1,00 \%$ \\
\hline \multicolumn{1}{c}{ Efek samping } & yangm dari & pengounaan \\
\hline NA & 1 & \\
\hline
\end{tabular}

Efek samping yang umum dari penggunaan

NSAID adalah toksisitas gangguan saluran pencernaan, meliputi dispepsia, ulcer, perdarahan saluran cerna, hingga terjadinya perforasi ${ }^{2,20,22}$.

Resiko relatif terhadap ulcer bersifat rendah oleh aceclofenak, celecoxib, dan ibuprofen; sedang meloxicam, diklofenak, dan ketoprofen; resiko tinggi oleh naproxen, indometasin,diflunisal, dan yang paling tinggi adalah piroxicam dan ketorolak ${ }^{21}$. Strategi yang digunakan untuk 
menurunkan toksisitas saluran pencernaan (dyspepsia, perdarahan, dan ulcer) adalah penggunaan NSAID dengan misoprostol, H2-Blocker atau PPI dan/atau penggunaan NSAID selektif (COX-2 selektif inhibitor) 2,20,22. . Penggunaan NSAID bersama dengan obat gastroprotektif sangat bermanfaat dalam mencegah efek samping pada saluran pencernaan terutama pada pasien lanjut usia ${ }^{24}$.

Faktor resiko yang dapat memperparah efek samping tersebut adalah usia lebih dari 65 tahun, mempunyai riwayat peptic ulcer disease, penyakit jantung, penggunaan bersamaan obat antiplatelet, antikoagulan, dan kortikosteroid ${ }^{15,19,21,22}$. Kejadian ini dapat terjadi hingga $30 \%$ dari pemakaian NSAID secara kronis ${ }^{25}$. Hal ini dikarenakan NSAID yang bersifat non selektif menghambat kerja COX1, suatu enzim yang berperan dalam menghasilkan prostaglandin sebagai proteksi alami lambung. Penghambatan jangka panjang sekresi asam lambung diperlukan dalam upaya pencegahan ulcer gastroduodenal selama penggunaan aspirin atau NSAID lainnya ${ }^{26}$.

Faktor resiko juga muncul dari sifat keasaman NSAID (nilai $\mathrm{pKa})^{15}$. Semakin rendah nilai $\mathrm{pKa}$ dapat meningkatkan permeabilitas saluran cerna yang akan berakibat terjadinya inflamasi. Peningkatan permeabilitas berakibat kehilangan fungsi barrier saluran cerna. Hal ini menyebabkan bakteri dan zat di luar saluran pencernaan dapat masuk ke dalam mukosa ${ }^{27}$.

Menurut The American College of Gastroenterology, pasien dengan resiko tinggi terjadinya efek samping saluran pencernaan direkomendasikan untuk dilakukan kombinasi dengan selektif COX2-inhibitor dan/atau misoprostol atau dosis tinggi PPI. Hal yang serupa dalam penelitian lain bahwa dari hasil endoskopi menunjukkan misoprostol, PPI, dan dosis tinggi H2blocker efektif dalam mencegah ulcer usus dan lambung yang diakibatkan NSAID ${ }^{2}$. Penggunaan bersamaan NSAID dengan obat gastoprotektif terbukti bersifat cost-effective dibandingkan monoterapi NSAID. Kombinasi NSAID-PPI terbukti paling cost-effective dibandingkan gastroprotektif lainnya ${ }^{22}$.

Tabel 3. Perbandingan nilai pKa NSAID ${ }^{15}$

\begin{tabular}{ll}
\hline Jenis NSAID & Nilai pKa \\
\hline Valdecoxib & 9.8 \\
\hline Celecoxib & 9.7 \\
\hline Nimesulide & 6.4 \\
\hline Ibuprofen & 5.2 \\
\hline Lumiracoxib & 4.7 \\
\hline Etoricoxib & 4.5 \\
\hline Indomethacin & 4.5 \\
\hline Naproxen (enteric-coated) & 4.2 \\
\hline Diclofenac & 4.0 \\
\hline ASA (enteric-coated) & 3.5 \\
\hline
\end{tabular}

Proton Pump Inhibitor (PPI) bekerja menurunkan sekresi asam lambung dengan menghambat pompa $\mathrm{H}^{+} / \mathrm{K}^{+}$ATPase. PPI lebih efektif dibandingkan H2-blocker dan menjadi terapi lini pertama dalam pencegahan ulcer gastroduodenal akibat pemakaian NSAID $^{2,17,21,26,28}$. PPI bersifat poten dan menghambat sekresi asam lambung dalam jangka waktu yang lama ${ }^{15}$. Pemakaian PPI selama 613 bulan dapat menurunkan angka kekambuhan hinga 1/10 dibandingkan placebo ${ }^{26}$. Penggunaan PPI jangka panjang dapat menimbulkan efek samping diare akibat Clostridiumdifficile, community-acquired pneumonia, osteoporosis, dan fraktur jika dibandingkan dengan H2-blocker ${ }^{2,28}$. Perpanjangan durasi pemakaian dan peningkatan dosis memperparah efek samping tersebut ${ }^{2}$.

H2-blocker mengurangi sekresi asam lambung dengan cara memblok reseptor histamine tipe 2 secara kompetitif pada sel parietal. H2-blocker dapat menekan produksi asam lambung $37-68 \%$ selama 24 jam. H2blocker secara signifikan efektif mencegah dan mengobati ulcer usus dan lambung jika digunakan pada dosis tinggi. Akan tetapi, jika digunakan pada dosis lazim hanya efektif terhadap ulcer usus ${ }^{2}$.

Obat yang diperlukan untuk mengurangi efek samping NSAID tidak hanya bekerja menekan/mengurangi sekresi asam lambung, tetapi juga ada yang bersifat sebagai proteksi mukosa lambung (cytoprotective). Sukralfat, suatu garam alumunium dari sulfated-polysaccharide, bersifat cytoprotective yang bekerja dengan meningkatkan jumlah mucus dan melindungi mukosa lambung. Sukralfat terbukti efektif dalam mengurangi lesi pada mukosa lambung ${ }^{23}$. Sukralfat bekerja berbeda dari obat penetral asam lambung dan antisekretori asam lambung. Sukralfat bekerja dengan cara meningkatkan sekresi PGE2 dari mukosa lambung, faktor pertumbuhan epidermal dan reseptornya. Sukralfat mampu melindungi luka dari asam lambung dan pepsin. Sukralfat secara signifikan mampu mengurangi jumlah lesi pada mukosa lambung dibandingkan placebo, tetapi tidak signifikan pada mukosa usus dan gejala gastropati ${ }^{29}$. Sebaliknya, sukraflat dan placebo tidak berbeda secara signifikan dalam menyembuhkan lesi lambung ${ }^{30}$.

Sukralfat 1 gram digunakan 4 kali sehari dibandingkan ranitidine $150 \mathrm{mg}$ dua kali sehari menunjukkan tingkat penyembuhan yang mirip (83\% vs 84\%). Omeprazol $20 \mathrm{mg}$ sekali sehari memiliki keefektifan yang lebih tinggi di bandingkan sukralfat 1 gram dua kali sehari dalam mengurangi lesi dan gejala ulkus baik lambung maupun usus ${ }^{30}$.

Antasida merupakan obat yang bekerja mengalkalinisasi asam lambung. Antasida mencapai 87,3\% diresepkan bersamaan dengan NSAID. Peresepan ini terbanyak pada bagian ortopedi. Peresepan juga dilakukan oleh bagian penyakit dalam dengan frekuensi yan glebih tinggi ketika digunakan juga kortikosteroid atau adanya diagnose penyakit pada bagian esophagus, lambung, usus. Antasida juga secara signifikan diresepkan dengan NSAID ketika antitukak lain juga digunakan. Antasida tidak terbukti efektif dalam emcegah efek samping dari NSAID. Bahkan beberapa studi menyatakan penggunaan bersama antasida dan NSAID mempertinggi resiko komplikasi gangguan saluran cerna bagian atas ${ }^{19}$.

Hasil penelitian ini menunjukkan bahwa $22 \%$ pasien berpotensi mengalami interaksi antara NSAID yang digunakan dengan obat lain yang digunakan bersamaan. Jenis interaksi NSAID dengan obat lainnya dapat dilihat 
pada tabel 4.

Tabel 4. Jenis Interaksi NSAID dengan obat lain yang diresepkan

\begin{tabular}{lc}
\hline \multicolumn{1}{c}{ Jenis Interaksi NSAID } & $\begin{array}{c}\text { Jumlah } \\
\text { Sampel }\end{array}$ \\
\hline Piroxicam-Cefadroxil & 1 \\
Ibuprofen-kalium diklofenak & 4 \\
Kalium diklofenak-metilprednisolon & 5 \\
Meloxicam-prednison & 3 \\
Meloxicam-aspirin & 1 \\
Meloxicam-metilprednisolon & 4 \\
Natrium dikofenak-kaptopril & 1 \\
Kalium diklofenak-aspirin & 1 \\
Meloxicam-candesartan-digoxin-furosemid & 1 \\
Diklofenak-Metilpredinisolon-Ibuprofen & 1 \\
\hline
\end{tabular}

Total

Tiga belas dari 22 pasien (59\%) yang mengalami interaksi merupakan interaksi antara NSAID dengan kortikosteroid (metilprednisolon dan prednison). Kortikosteroid merupakan antiinflamasi yang berstruktur steroid yang bekerja pada jalur pembentukan mediator inflamasi. Penggunaan bersama kedua obat ini dapat mengakibatkan peningkatkan resiko ulcer pada saluran pencernaan. Hal ini dikarenakan keduanya bekerja tidak selektif pada COX1 sehingga proteksi alami lambung semakin berkurang ${ }^{18,32,45}$.

Tujuh dari 22 pasien (32\%) mengalami interaksi akibat pemakaian dua jenis NSAID. Kombinasi dua NSAID meliputi diklofenak- ibuprofen, meloxicam-aspirin, diklofenak-aspirin. Aspirin atau asam asetilsalisilat yang digunakan dalam penelitian ini dengan kekuatan $80 \mathrm{mg}$. Salah satu pasien dalam penelitian ini yang menggunakan aspirin terdiagnosa juga stroke. Aspirin dengan kekuatan $80 \mathrm{mg}$ lebih mempunyai efek antiplatelet, pencegahan infark miokardial, dan penyakit jantung lainnya dibandingkan antiinflamasi ${ }^{46,47}$. Hasil interaksi ini berupa efek antikoagulasi meningkat, serum kalium meningkat, serta NSAID yang digunakan kadarnya meningkat dalam tubuh $^{33}$. Hasil sistematik review menyatakan bahwa terdapat bukti bahwa penggunaan bersama beberapa NSAID, tidak semua NSAID, dapat menghambat efek antiplatelet aspirin. Naproxen, ibuprofen, meloxicam dan rofecoxib tidak mempengaruhi efek kardioprotektif aspirin $^{46}$. Penggunaan bersama ibuprofen-aspirin meningkatkan mortality penyakit kardiovaskuler dibandingkan dnegan penggunaan tunggal aspirin. Interaksi antara NSAID dan aspirin dapat dikurangi dengan memberi jarak ketika minum obat ${ }^{34}$.

Interaksi lainnya yang terjadi adalah NSAID dengan candesartan, digoksin, furosemide, dan kaptopril. Pasien yang menggunakan kombinasi candesartan, digoksin, dan furosemide terdiagnosa gagal jantung kongestif $(\mathrm{CHF})$ sedangkan pasien yang menggunakan kaptopril terdiagnosa hipertensi. NSAID melemahkan efek antihipertensi dari diuretik, beta blocker, angiotensinconverting enzyme inhibitors (ACEIs), vasodilator, alfa-2 agonis, alfa-1 antagonis, dan angiotensin II blocker ${ }^{35}$.

Penggunaan bersama NSAID dengan antihipertensi dapat mengurangi efek antihipertensi dikarenakan sintesis prostaglandin yang bersifat vasodilator terhambat. NSAID dapat meningkatkan tekanan darah systole $<5 \mathrm{mmHg}$. Prostaglandin bekerja secara local pada ginjal untuk mempertahankan homoestasis melalui pengaturan reabsorpsi natrium dan air. Prostaglandin menghambat sintesis endothelin-1 ginjal sehingga menurunkan reabsorpsi air dan natrium. Beberapa studi menyatakan bahwa penggunaan bersama NSAID dan obat antihipertensi masih tetap menaikkan tekanan darah ${ }^{35}$. Peningkatan tekanan darah khususnya sistole perlu dilakukan monitoring khususnya pada pasien yang memperoleh NSAID dosis tinggi dan etoricoxib sebaiknya tidak digunakan pada pasien hipertensi ${ }^{36}$. Penggunaaan diuretik dan Angiotensin Converting enzyme inhibitor (ACEI) atau angiotensin receptor blocker (ARB) bersamaan dengan NSAID dapat meningkatkan resiko terjadi gagal ginjal akut ${ }^{37}$.

Variabel-variabel usia, jenis kelamin, jenis NSAID, dan jenis diagnosa tidak memiliki hubungan yang bermakna dengan kejadian interaksi obat, seperti terlihat pada tabel $5,6,7,8,9$.

Tabel 5. Hubungan Antara Jenis Kelamin dan Potensi Interaksi Obat

\begin{tabular}{|c|c|c|c|c|c|c|}
\hline & \multicolumn{4}{|c|}{ Potensi Interaksi Obat } & \multirow{3}{*}{$\mathrm{P}$} & \multirow{3}{*}{ OR (IK 95\%) } \\
\hline & \multicolumn{2}{|c|}{ Ada } & \multicolumn{2}{|c|}{ Tidak Ada } & & \\
\hline & $\mathrm{n}$ & $\%$ & $\mathrm{n}$ & $\%$ & & \\
\hline Laki-laki & 8 & 36,4 & 36 & 46,2 & 0,414 & $\begin{array}{l}0,667(0,251- \\
1,769)\end{array}$ \\
\hline Perempuan & 14 & 63,6 & 42 & 53,8 & & Pembanding \\
\hline Total & 22 & 100 & 78 & 100 & & \\
\hline
\end{tabular}

Nilai p sebesar $0,414(>0,05)$ yang bermakna bahwa jenis kelamin tidak berpengaruh pada kejadian potensi interaksi obat. Nilai OR sebesar 0,667 yang bermakna bahwa kelompok laki-laki memiliki resiko 0,667 lebih besar dibandingkan perempuan, dengan kata lain perempuan lebih beresiko dibandingkan laki-laki.

Tabel 6. Hubungan Antara Usia dan Potensi Interaksi Obat

\begin{tabular}{lllllll} 
& \multicolumn{3}{c}{ Potensi Interaksi Obat } & & \\
\cline { 2 - 4 } $\begin{array}{l}\text { Usia } \\
\text { (tahun) }\end{array}$ & \multicolumn{2}{c}{ Ada } & \multicolumn{2}{c}{ Tidak Ada } & & \multicolumn{1}{c}{ OR (IK 95\%) } \\
\cline { 2 - 4 } & $\mathrm{n}$ & $\%$ & $\mathrm{n}$ & $\%$ & & \\
$0-17$ & 1 & 4,5 & 1 & 1,3 & 1,00 & $1,00(0,02-$ \\
$18-65$ & 18 & 81,9 & 60 & 76,9 & 0,403 & $50,397)$ \\
$66-79$ & 2 & 9,1 & 16 & 20,5 & 1,94 & $3,33(0,198-$ \\
$>80$ & 1 & 4,5 & 1 & 1,3 & & $56,00)$ \\
& & & & & & $8,00(0,347-$ \\
& & & & & & $184,36)$ \\
& & & & & & Pembanding \\
\hline
\end{tabular}

$\begin{array}{lllll}\text { Total } & 22 & 100 & 78 & 100 \\ & \text { Nilai } p \text { pada kelompok usia berada di atas } 0,05\end{array}$ yang bermakna bahwa tidak ada hubungan signifikan antar kelompok terhadap kejadian potensi interaksi obat. Nilai OR kelompok 0-17 tahun sebesar 1,00 mempunyai makna kelompok usia ini memiliki resiko yang sama dengan kelompok > 80 tahun. Resiko yang lebih tinggi dari kedua kelompok tersebut secara berurutan adalah kelompok 1865 tahun kemudian kelompok 66-79 tahun.

Tabel 7. Hubungan Antara Jenis NSAID dengan Potensi Interaksi 


\begin{tabular}{lllllll}
\multicolumn{7}{c}{ Obat } \\
\cline { 2 - 4 } Jenis NSAID & \multicolumn{7}{c}{ Ada } & \multicolumn{2}{c}{ Tidak } & OR (IK 95\%) \\
\cline { 2 - 5 } & \multicolumn{7}{c}{ Ada } & & \\
\cline { 2 - 5 } Asam & $\mathrm{n}$ & $\%$ & $\mathrm{n}$ & $\%$ & \\
mefenamat & 0 & 0 & 1 & 1,3 & 0,999 & 2,61 \\
Diklofenak & 8 & 36,5 & 41 & 52,6 & 0,999 & 8,27 \\
Ibuprofen & 1 & 4,5 & 1 & 1,3 & 0,999 & 1,615 \\
Ketoprofen & 0 & 0 & 2 & 2,7 & 0,999 & 2,61 \\
Piroksikam & 1 & 4,5 & 2 & 2,7 & 0,999 & 3,231 \\
Meloksikam & 7 & 31,8 & 18 & 23,1 & 0,999 & 4,15 \\
Etoricoxib & 0 & 0 & 13 & 16,7 & 0,998 & 2,61 \\
Diklofenak- & 5 & 22,7 & 0 & 0 & & Pembanding \\
Ibuprofen & & & & & \\
\hline Total & 22 & 100 & 78 & 100 & & \\
\hline
\end{tabular}

Nilai p mempunyai nilai lebih besar dari 0,05 yang bermakna bahwa tidak ada hubungan jenis NSAID dengan potensi interaksi obat. Berdasarkan nilai OR, resiko terjadinya potensi interaksi obat dari yang terendah hingga tertinggi adalah diklofenak kombinasi ibuprofen, ibuprofen, etoricoxib-ketoprofen-asam mefenamat (ketiganya memiliki potensi yang sama), piroksikam, meloksikam, diklofenak.

Tabel 8. Hubungan Jumlah Obat dengan Potensi Interaksi Obat

\begin{tabular}{|c|c|c|c|c|c|c|}
\hline & \multicolumn{4}{|c|}{ Potensi Interaksi Obat } & \multirow{3}{*}{$\mathrm{P}$} & \multirow{2}{*}{ OR (IK 95\%) } \\
\hline & \multicolumn{2}{|r|}{ Ada } & \multicolumn{2}{|c|}{ Tidak Ada } & & \\
\hline & $\mathrm{n}$ & $\%$ & $\mathrm{n}$ & $\%$ & & \\
\hline$<5$ obat & 12 & 54,5 & 56 & 71,8 & & pembanding \\
\hline$\geq 5$ obat & 10 & 45,5 & 22 & 28,2 & 0,126 & $\begin{array}{l}2,121(0,801- \\
5,615)\end{array}$ \\
\hline Total & 22 & 100,0 & 78 & 100,0 & & \\
\hline $\begin{array}{l}\text { tidak ac } \\
\text { potensi } \\
\text { sebesar } \\
\text { bermak } \\
\text { sama de } \\
\text { mengal }\end{array}$ & $\begin{array}{l}\text { Nila } \\
\text { a hul } \\
\text { intera } \\
2,12 \\
\text { a ba } \\
\text { ngan } \\
\text { mi pr }\end{array}$ & $\begin{array}{l}\text { p lebil } \\
\text { ungan } \\
\text { ksi oba } \\
\text { deng } \\
\text { lwa pa } \\
5 \text { mem } \\
\text { tensi ir }\end{array}$ & IK & $\begin{array}{l}\text { dari } 0 \text {, } \\
\text { xan ant } \\
\text { neter } \mathrm{k} \\
95 \% \\
\text { engan } \\
\text { kemun } \\
\text { obat. }\end{array}$ & $\begin{array}{l}5 \text { yang } \\
\text { ra jum } \\
\text { kuatan } \\
0,801-5 \\
\text { jumlah } \\
\text { kinan }\end{array}$ & $\begin{array}{l}\text { hempunyai arti } \\
\text { h obat dengan } \\
\text { ubungan (OR) } \\
15 \text {. Hal ini } \\
\text { bat lebih dari } \\
121 \text { kali untuk }\end{array}$ \\
\hline
\end{tabular}

Tabel 9. Hubungan antara Jenis Penyakit Muskuloskeletal dengan

\begin{tabular}{|c|c|c|c|c|c|c|}
\hline \multirow{3}{*}{ Jenis Penyakit } & \multicolumn{4}{|c|}{ Potensi Interaksi Obat } & \multirow{3}{*}{$\mathrm{P}$} & \multirow{3}{*}{ OR (IK 95\%) } \\
\hline & \multicolumn{2}{|c|}{ Ada } & \multicolumn{2}{|c|}{$\begin{array}{c}\text { Tidak } \\
\text { Ada }\end{array}$} & & \\
\hline & $\mathrm{n}$ & $\%$ & $\mathrm{n}$ & $\%$ & & \\
\hline Gonarthrosis & 4 & 18,2 & 16 & 20,5 & 0,678 & $\begin{array}{l}0,706 \\
(0,136-3,658)\end{array}$ \\
\hline $\begin{array}{l}\text { Artritis } \\
\text { Unspesifik }\end{array}$ & 5 & 22,7 & 15 & 19,2 & 0,433 & $\begin{array}{l}0,529 \\
(0,108-2,598)\end{array}$ \\
\hline Radiculopathy & 6 & 27,3 & 14 & 18,0 & 0,264 & $\begin{array}{l}0,412 \\
(0,087-1,952)\end{array}$ \\
\hline $\begin{array}{l}\text { Nyeri } \\
\text { punggung } \\
\text { bawah }\end{array}$ & 4 & 18,2 & 16 & 20,5 & 0,678 & $\begin{array}{l}0,706 \\
(0,136-3,658)\end{array}$ \\
\hline Mialgia & 3 & 13,6 & 17 & 21,8 & & Pembanding \\
\hline Total & 22 & 100 & 78 & 100 & & \\
\hline
\end{tabular}

Nilai p mempunyai nilai lebih besar dari 0,05 yang bermakna bahwa tidak ada hubungan jenis penyakit dengan potensi interaksi obat. Berdasarkan nilai OR, potensi interaksi obat dari urutan yang terkecil hingga terbesar berdasarkan jenis penyakit yaitu radiculopathy, artritis unspesifik, nyeri punggung bawah-gonarthrosis (memiliki potensi yang sama), dan mialgia.

Lima penyakit muskuloskeeltal terbanyak dalam penelitian ini berdasarkan diagnosa ICD-10 adalah gonarthoris, arthritis unspesifik, radiculopathy, nyeri punggung bawah, dan mialgia. Gonarthrosis merupakan penyakit pada sendi, bersifat degenerative akibat pertambahan usia. Bagian yang terkait dengan diagnose ini adalah lutut. Diagnosa ini disebut juga knee osteoarthritis $^{48}$. Penatalaksanaan gonarthrosis menggunakan NSAID sebagai lini pertama. NSAID oral diberikan jika NSAID topical tidak efektif. Jika tidak cukup efektif atau emngalami efek samping yang serius, glukosmain, asam hialuronat, kortikosteroid menjadi pilihan selanjutnya. Analgetika opioid sebagai lini terakhir dalam mengatasi nyeri ini $^{38}$.

Pengobatan artritis dapat menggunakan terapi sistemik atau lokal, keduanya terbukti eektif. Terapi yang digunakan dapat berupa parasetamol, analgesic opioid, NSAID, anti-sitokin, serta kombinasi antar obat tersebut. Obat non per oral yang biasa digunakan adalah NSAID topical, injeksi steroid articular, injeksi asam hialuronat articular. Asam hialuronat merupakan polisakarida bermassa besar yang mempunyai aktifitas yang luas. Obat ini digunakan dalam terapi simtomatik osteoarthritis. Manfaat yang diperoleh sama dengan injeksi steroid. Walaupun onset kerjanya lebih lama, efeknya mampu bertahan hingga 12 bulan. Glucosamin dan chrondroitin seakrang ini sebagai pengobatan popular osteoarthritis walaupun percobaan skala besar menunjukkan manfaat yang tidak signifikan dibandingkan placebo ${ }^{39}$.

Radiculopathy merupakan terjepitnya akar syaraf pada ruas tulang belakang. Radiculopathy dibedakan berdasarkan lokasinya di ruas tulang belakang, seperti leher, lumbar, sakral. Pengobatan secara farmakologi meliputi NSAID sebagai lini pertama. Pemberian oral kortokosteroid dapat diberikan secara bertahap pada keadaan akut. Terapi selanjutnya adalah dengan memberikan suntikan, yang terdiri dari injeksi epidural steroid, injeksi facet, injeksi transforaminal yang sangat membantu mengurangi gejala dalam jangka panjang. Injeksi ini umumnya mengandung kombinasi antiinflamasi seperti glukokortikoid dan anestesi durasi panjang, seperti Marcaine ${ }^{40}$. Menurut The North American Spine Society, standar terapi pada lumbar radiculopathy adalah dengan menggunakan NSAID, tramadol, atau parasetamol. Penggunaan IV glukokortikoid, 5-HT reseptor inhibitor, gabapentin, agmatine sulfat, amitriptilin masih memerlukan bukti yang cukup untuk menjadi terapi radiculopathy. Monoterapi gabapentin dapat mengurangi nyeri dan secara meningkatkan jarak berjalan dari pasien radiculopathy. Penambahan amitriptilin pada injeksi epidural steroid secara signifikan bermanfaat dibandingkan placebo dan injeksi injeksi epidural steroid ${ }^{41}$. Walaupun pengobatan dengan obat belum terbukti efektif pada radiculopathy leher, tetapi terbukti bermanfaat pada 
radiculopathy lumbar dan nyeri punggung bagian bawah, menjadikan pengobatan ini berpotensi untuk digunakan. NSAID efektif pada nyeri punggung bawah akut dan ini digunakan akhirnya digunakan juga untuk nyeri leher radiculopathy yang menjalar ke lengan. Beberapa pasien memperoleh manfaat dengan penambahan analgetika narkotik, relaksan otot, antidepresan dan antikonvulsan. Pengobatan efektif bagi pasien radiculopathy kronik yang gagal dari pembedahan atau masih tetap merasakan nyeri setelah pembedahan. Hasil sistematik review menyatakan bahwa antidepresan trisiklik dan venlafaxine menunjukkan pengurangan rasa nyeri hingga tingkat sedang pada nyeri neuropati. Begitu juga dengan penggunaan tramadol. Kortikosteroid oral digunakan secara luas dalam nyeri akut radiculopathy walaupun bukti kemanjuran belum mencukupi. Pemberikan suntikan steroid melalui leher sebagai pilihan dalam penanganan radiculopathy leher ${ }^{42}$.

Nyeri punggung bawah merupakan penyakit umum yang diderita manusia dewasa, mencapai $84 \%$ dan hampir 50\% nya mengalami kejadian lebih dari sekali. Terapi dengan NSAID telah terbukti untuk mengatasi nyeri akut nyeri punggung bawah dibandingkan plasebo. Enam puluh sembilan persen pasien di Amerika Serikat yang mengunjungi dokter pertama kali dengan keluhan nyeri punggung bawah diresepkan NSAID dan 4\% parasetamol. Penelitian yang dilakukan di Belanda menunjukkan bahwa dokter umum meresepkan NSAID terhadap $45 \%$ seluruh keluhan pasien. Opiod kerja sedang mempunyai efektivitas yang sama. Selain itu, antidepresan golongan trisiklik mempunyai manfaat pada pasien ini dibandingkan golongan SSRI. Mekanisme kerjanya diduga karena nyeri punggung bawah kronik sebagai manifestasi dari depresi, antidepresan mempunya efek sedatif, dan antidepresan mempunyai sifat intrinsik analgesia. Sebuah survey menunjukkan $91 \%$ dokter umum pada fasilitas kesehatan tingkat pertama meresepkan relaksan otot, berbeda halnya dengan survey lain yang mencapai 35-64\% untuk mengatasi akut nyeri punggung bawah selama 7-14 hari. Sebuah sistematik review yang dilakukan, relaksan otot (benzodiazepine, non benzodiazepine, antispastik ) lebih efektif dibandingkan plasebo untuk nyeri singkat pada akut dan kronis nyeri punggung bawah. Banyak guideline menjadikan relaksan otot sebagai lini kedua jika analgesia/NSAID tidak efektif. Hal ini dikarenakan dengan efek samping dan ketergantungan. $69 \%$ pasien memeperoleh manfaat yang signifikan dengan kombinasi NSAID/analgesia dan relaksan otot ${ }^{43}$.

Relaksan otot merupakan kelas dari obat-obat yang secara struktur kimia tidak mirip, yang dikelompokkan karena kesamaan indikasi ${ }^{48}$. Golongan ini dikategorikan menjadi 2, yakni agen antispastik dan agen antispasmodik. Agen antispastik bekerja melalui korda spinalis atau otot rangka secara langsung untuk meningkatkan hipertonisitas otot dan spasme involunter, sedangkan agen antispasmodik bekerja dengan mengurangi spasme otot melalui perubahan konduksi sistem saraf pusat. Contoh obat golongan ini antara lain eperisone, tizanidine (agonis $\alpha-2$ ), orphenadrine (antagonis kolinergik muskarinik, antihistamin), carisoprodol (GABA-ergic), baclofen (agonis GABA-B), dan benzodizepin ${ }^{31}$. Golongan benzodiazepine paling banyak diresepkan di Australia dibandingkan dengan di Amerika. Sedangkan carisoprodol dan cyclobenzaprin paling banyak digunakan. Diazepam baik di Australia dan Amerika Serikat merupakan golongan benzodiazepine yang paling umum digunakan. Akan tetapi, efikasi relaksan otot dalam terapi nyeri punggung bawah masih perlu dibuktikan kembali ${ }^{48}$.

\section{Daftar Pustaka}

1. WHO. Musculosceletal conditions (fact sheets). 2018. [Updated 2019 November 26, cited 2020 Oktober 10] Available from https://www.who.int/news-room/factsheets/detail/musculoskeletal-conditions

2. Tuskey A, Peura, D. The use of H2 antagonists in treating and preventing NSAID-induced mucosal damage. Arthritis Research and Therapy. 2013; 15(Supl 3):1-7

3. Loveless M S, Fry, AL. Pharmacologic Therapies in Musculoskeletal Conditions. Medical Clinics of North America. 2016; 100(4): 869-890.

4. Qaseem A, Wilt TJ, McLean RM, Forciea MA. Noninvasive treatments for acute, subacute, and chronic low back pain: A clinical practice guideline from the American College of Physicians. Annals of Internal Medicine. 2017; 166(7): 514-530.

5. Farooqui R,Hoor T,Karim N, Muneer M. Potential Drug-Drug Interactions among patient's prescriptions collected from Medicine out-patient setting. Pakistan Journal of Medical Sciences. 2018; 34(1):144-148

6. Cascorbi, I. Drug Interactions-Principles, Examples and Clinical Consequences. Deutsches Arzteblatt International. 2012; 109(33-34): 546-556.

7. Skvrce MN, Šarinić MV, Mucalo I, Krnić D, Božina $\mathrm{N}$, Tomić S. Adverse drug reactions caused by drugdrug interactions reported to Croatian Agency for Medicinal Products and Medical Devices: a retrospective observational study. Croatian Medical Journal. 2011; 52(5): 604-614

8. Palleria C, Di Paola A, Galelli L. Pharmacokinetic drug-drug interaction and their implication in clinical management. J Res Med Sci. 2013;18(7):601-610.

9. Bihari V, Kesavachandran C, Pangtey B S, Srivastava AK, Mathur N. Musculoskeletal pain and its associated risk factors in residents of national capital region. Indian Journal of Occupational and Environmental Medicine. 2011; 15(2): 59-63

10. Woolf AD, Pfleger B. Burden of major musculoskeletal conditions. Bulletin of the World Health Organization. 2003; 81(9): 646-656.

11. Nakua EK, Otupiri E, Dzomeku VM, Owusu-dabo E, Agyei-baffour P, Yawson AE, Folson G, Hewlett S. Gender disparities of chronic musculoskeletal disorder burden in the elderly Ghanaian population: study on global ageing and adult health (SAGE 
WAVE 1). BMC Musculoskeletal Disorders. 2015; 16(204): 1-10

12. Cavallari JM, Ahuja M, Dugan AG, Meyer JD, Simcox N, Sciences $\mathrm{OH}$, et al. Differences in the prevalence of musculoskeletal symptoms among female and male custodians. Am J Ind Med. 2017; 59(10): 841-852

13. Wolf JM, Cannada L, Heest AEV, Connor MIO, Ladd AL. Male and Female Differences in Musculosceletal Disease. Journal of the American Academy of Orthopaedic Surgeons. 2015; 23(6): 339-347.

14. Pelletier J, Martel-pelletier J, Rannou F, Cooper, C. Efficacy and safety of oral NSAIDs and analgesics in the management of osteoarthritis: Evidence from real-life setting trials and surveys. Seminars in Arthritis and Rheumatism. 2016;45(4): 22-27

15. Gwee KA, Goh V, Lima G, Setia S. Coprescribing proton-pump inhibitors with nonsteroidal antiinflammatory drugs: Risks versus benefits. Journal of Pain Research. 2018; 11: 361-374

16. Kołodziejska J, Kołodziejczyk M. Diclofenac in the treatment of pain in patients with rheumatic diseases. Reumatologia .2018; 56(3): 174-183

17. Ong C, Lirk P, Tan C H, Seymour, RA. An EvidenceBased Update on Nonsteroidal Anti-Inflammatory Drugs. Clinical Medicine \& Research. 2007; 5(1): 19-34

18. Hodgson, E. The effects of corticosteroids and nonsteroidal anti-inflammatory drugs, including aspirin, on coagulation. South African Family Practice. 2015; 57(5): 9-12

19. Liu JY,Chen TJ, Hwang SJ. Concomitant prescription of non-steroidal anti-inflammatory drugs and antacids in the outpatient setting of a medical center in Taiwan: A prescription database study. European Journal of Clinical Pharmacology. 2001; 57(5-6): 505-508

20. Wongrakpanich S, Wongrakpanich A, Melhado K, Rangaswami J. A Comprehensive Review of NonSteroidal Anti- Inflammatory Drug Use in The Elderly. Aging and Disease. 2018; 9(1): 143-150

21. Drini M. Peptic ulcer disease and non-steroidal antiinflammatory drugs. Australian Prescriber. 2017; 40(3): 91-93

22. De Groot NL, Spiegel BMR, Van Haalen HGM, De Wit NJ, Siersema PD, Van Oijen MGH. Gastroprotective strategies in chronic NSAID users: A cost-effectiveness analysis comparing single-tablet formulations with individual components. Value in Health. 2013; 16(5): 769-777

23. Caldwell JR, Roth SH, Wu WC, Semble EL, Castell DO, Heller MD, Marsh WH. Sucralfate treatment of nonsteroidal anti-inflammatory drug-induced gastrointestinal symptoms and mucosal damage. The American Journal of Medicine. 1987; 83(3 SUPPL. 2): 74-82

24. Medlock S, Eslami S, Askari M, Taherzadeh Z, Opondo D, de Rooij SE, et al. Co-prescription of gastroprotective agents and their efficacy in elderly patients taking nonsteroidal anti-inflammatory drugs: A systematic review of observational studies. Clinical Gastroenterology and Hepatology. 2013; 11(10): 1259-1269

25. Wehling M. Non-steroidal anti-inflammatory drug use in chronic pain conditions with special emphasis on the elderly and patients with relevant comorbidities: management and mitigation of risks and adverse effects. Eur J Clin Pharmacol. 2014; 70: 1159-1172

26. Kinoshita Y, Ishimura N, Ishihara S. Advantages and disadvantages of long-term proton pump inhibitor use. Journal of Neurogastroenterology and Motility. 2018; 24(2): 182-196

27. Chamoun-Emanuelli AM, Bryan LK, Cohen ND, Tetrault TL, Szule JA, Barhoumi R, WhitfieldCargile CM. NSAIDs disrupt intestinal homeostasis by suppressing macroautophagy in intestinal epithelial cells. Scientific Reports. 2019; 9(1): 1-15.

28. Mo C, Sun G, Wang YZ, Lu ML, Yang, YS. PPI versus histamine $\mathrm{H} 2$ receptor antagonists for prevention of upper gastrointestinal injury associated with low-dose aspirin: Systematic review and metaanalysis. PLoS ONE. 2015; 10(7): 1-13.

29. Malagelada JR, Rodríguez de La Serna A, Dammann HG, Pons M, Armas C, Sala M, et al. Sucralfate therapy in NSAID bleeding gastropathy. Clinical Gastroenterology and Hepatology. 2003; 1(1): 51-56.

30. Bianchi Porro G, Lazzaroni M , Manzionna G , Petrillo M. Omeprazole and sucralfate in the treatment of NSAID-induced gastric and duodenal ulcer. Alimentary Pharmacology and Therapeutics. 1998; 12(4): 355-360

31. Rizki MM, Saftarina F. Tatalaksana Medikamentosa pada Low Back Pain Kronis. Majority. 2020; 9 (1): $1-7$.

32. Amrulloh FM, Utami N. Hubungan Konsumsi OAINS terhadap Gastritis. Majority,. 2016; 5: 18-21.

33. Medscape.Drug Interaction Checker. https://reference.medscape.com/druginteractionchecker

34. Shibata K, Akagi Y, Nozawa N, Shimomura H, Aoyama T. Influence of nonsteroidal antiinflammatory drugs on aspirin's antiplatelet effects and suggestion of the most suitable time for administration of both agents without resulting in interaction. Journal of Pharmaceutical Health Care and Sciences. 2017; 3(1): 1-10

35. Frishman WH. Effects of nonsteroidal antiinflammatory drug therapy on blood pressure and peripheral edema. American Journal of Cardiology. 2002; 89(6 SUPPL 1): 18-25.

36. Floor-Schreudering A, De Smet PA, Buurma H, Kramers C, Tromp PC, Belitser SV, Bouvy, ML. NSAID-antihypertensive drug interactions: Which outpatients are at risk for a rise in systolic blood pressure? European Journal of Preventive Cardiology. 2015; 22(1): 91-99. 
37. Lapi F, Azoulay L, Yin H, Nessim SJ, Suissa, S. Concurrent use of diuretics, angiotensin converting enzyme inhibitors, and angiotensin receptor blockers with non-steroidal anti-inflammatory drugs and risk of acute kidney injury: Nested case-control study. BMJ (Online). 2013; 346(7890), 1-11

38. Steinmeyer J, Bock F, Stöve J, Jerosch J, Flechtenmacher J. Pharmacological treatment of knee osteoarthritis: Special considerations of the new German guideline. Orthopedic Reviews. 2018;10(7782):147-154

39. Kidd BL, Langford RM, Wodehouse T. Current approaches in the treatment of arthritic pain. Arthritis Research and Therapy. 2007; 9(3): 1-7.

40. Berry JA, Elia C, Saini HS, Miulli DE. A Review of Lumbar Radiculopathy, Diagnosis, and Treatment. Cureus. 2019;11(10): 1-7

41. North American Spine Society. Spine Care Diagnosis and Treatment of Lumbar Disc Herniation with Radiculopathy [document on internet]. 2012. [updated 2012; cited 2020 Oktober 12]. Available from: https://www.spine.org

42. Eubanks JD. Cervical Radiculopathy: Nonoperative Management of Neck Pain and Radicular Symptoms. American Family Physician. 2010; 81(1), 33-40

43. Mens JMA. The use of medication in low back pain. Best Practice and Research: Clinical Rheumatology. 2005; 19(4): 609-621

44. Zahra AP,Carolia N. Obat Anti-inflamasi Non-steroid ( OAINS ): Gastroprotektif vs Kardiotoksik. Majority. 2017; 6: 153-158

45. Alqahtani Z, Jamali F. Clinical outcomes of aspirin interaction with other non-steroidal antiinflammatory drugs: A systematic review. Journal of Pharmacy and Pharmaceutical Sciences. 2018; 21(1S): 48-73.

46. Meek IL, van de Laar MAFJ, Vonkeman HE. Nonsteroidal anti-inflammatory drugs: An overview of cardiovascular risks. Pharmaceuticals. 2010; 3(7):2146-2162

47. Solmaz I, Deniz S, Cifci OT. Treatment of advanced stage gonarthrosis with prolotherapy: Case report. Anesthesiology and Pain Medicine. 2014; 4(1): 1-4.

48. Abdel Shaheed C, Maher CG, Williams KA, McLachlan AJ. Efficacy and tolerability of muscle relaxants for low back pain: Systematic review and meta-analysis. European Journal of Pain (United Kingdom). 2017; 21(2): 228-237. 